\title{
HUBUNGAN ANTARA DUKUNGAN SOSIAL DENGAN MOTIVASI PASCA KESEMBUHAN PADA REMAJA PENYALAHGUNAAN NARKOBA DI BANDA ACEH
}

\author{
Julia Aridhona
}

Fakultas Psikologi, Universitas Muhammadiyah Aceh, juliaaridhona07070@gmail.com

\section{Barmawi}

Fakultas Psikologi, Universitas Muhammadiyah Aceh, barmawi@yahoo.com

\author{
Nursan Junita
}

Fakultas Psikologi, Universitas Muhammadiyah Aceh, nursaanjunita@yahoo.com

\begin{abstract}
Abstrak
Penelitian yang berjudul " Hubungan antara dukungan sosial dengan motivasi pasca kesembuhan pada remaja penyalahgunaan narkoba di Banda Aceh". Menggunakan metode kuantitatif yang bertujuan untuk melihat adanya hubungan antara dukungan sosial dengan motivasi pasca kesembuhan pada remaja penyalahgunaan narkoba. Sampel terdiri dari 40 orang remaja pasca penyalahgunaan narkoba di Banda Aceh dengan teknik sampling jenuh. Menggunakan analisis data dengan analisis korelasi product moment serta pengambilan data dengan menggunakan skala Likert. Hasil yang dilakukan menunjukkan adanya hubungan antara dukungan sosial dengan motivasi pasca kesembuhan pada remaja penyalahgunaan narkoba dengan nilai koefisien korelasi $r=0,819$ dengan nilai $p=0,000(p<0,05)$ artinya dukungan sosial berhubungan secara positif dengan motivasi.
\end{abstract}

Kata kunci : Dukungan sosial, motivasi kesembuhan, remaja

\begin{abstract}
The study entitled "The relationship between social support and post-healing motivation in drug abuse teenagers in Banda Aceh". Using quantitative methods that aim to see the relationship between social support and post-healing motivation in adolescent drug abuse. The sample consisted of 40 adolescents postdrug abuse in Banda Aceh with saturated sampling technique. Analysis with product moment correlation analysis and data retrieval using Likert scale. The result of the research shows that there is relationship between social support and post-healing motivation in adolescent drug abuse with correlation coefficient $r$ $=0,819$ with $\mathrm{p}=0,000(\mathrm{p}<0,05)$ meaning social support is positively correlated with motivation.
\end{abstract}

Keywords: Social support, healing motivation, adolescent

Di zaman yang moderen ini banyak terjadi berbagai macam masalah, salah satunya adalah masalah maraknya kasus penyalahgunaan narkoba dikalangan remaja yang mengkhawatirkan semua pihak baik pemerintah, masyarakat maupun orang tua. Banyak faktor yang dapat menyebabkan remaja mengalami penyalahgunaan narkoba diantaranya adalah pengaruh pergaulan, lingkungan tempat tinggal, ikut-ikutan teman, keluarga yang broken home yang dipengaruhi oleh kurangnya perhatian dan komunikasi antara orang tua dan anak, serta tekanan yang dialami dimasa remaja, sehingga remaja sangat rentan terpengaruh oleh perilaku-perilaku negatif.

Perilaku-perilaku masa remaja masih belum sepenuhnya memiliki pertimbangan yang matang contohnya mudah terpengaruh, mudah terombang ambing, emosi dan selalu ingin mencoba dan tidak mau ketinggalan (Gunarsa, 2001). Pada masa inilah sebagian remaja memiliki pengaruh yang berkaitan penyalahgunaan obat terlarang atau biasa disebut dengan narkoba.

Pengaruh penyalahgunaan narkoba disebabkan karena ketidakpahaman dan kurangnya pengetahuan remaja tentang bahaya narkoba, sehingga narkoba penting untuk diinformasikan kepada para remaja agar mereka tidak salah dalam mengambil tindakan dan perilaku-perilaku diusianya. Berdasarkan hal tersebut penting bagi pihak pemerintah, orang tua, sekolah untuk mendukung dan memberikan informasi yang berkaitan dengan masalah narkoba. Remaja dapat memiliki pengetahuan tentang penyalahgunaan narkoba, pengetahuan mengenai penyalahgunaan narkoba hanyalah merupakan salah satu segi yang perlu disampaikan agar mereka sadar akan dampak terhadap kesehatan bahkan ancaman terhadap kehidupan masa depannya (BNN, 2014).

Di Aceh yang tergolong kota kecil, jumlah pengguna dan pebisnis narkoba juga menunjukan peningkatan yang 
signifikan. Berbagai fakta memilukan kini terus mendera daerah ini (Tabrani, 2015). Menurut KBRN, Banda Aceh, berdasarkan data yang dirilis Badan Narkotika Nasional Provinsi (BNN, 2014) Aceh, Sejak tahun 2007 sampai dengan 2014 jumlah penyalahgunaan narkoba yang direhabilitasi sebanyak 540 orang, dengan rincian 501 orang direhabilitasi di Banda Aceh, sementara 39 orang lainnya diluar daerah. Dapat diperkirakan setiap tahun kasus penyalahgunaan narkoba terus meningkat.

Dukungan sosial merupakan informasi verbal atau non-verbal berupa pemberian saran, bantuan yang nyata atau tingkah laku yang diberikan oleh orang-orang yang akrab dengan subjek didalam lingkungan sosialnya atau berupa kehadiran orang-orang yang dapat memberikan keuntungan emosional atau berpengaruh pada tingkah laku penerimaan diri pada remaja penyalahgunaan narkoba, sehingga remaja memiliki penerimaan diri dengan lingkungannya (Sutanto, 2011).

Pada kenyataannya pengguna maupun mantan pengguna narkoba yang sudah direhabilitasi tetap dijauhi masyarakat. Masyarakat masih beranggapan bahwa mereka itu sampah masyarakat yang meresahkan lingkungan dan mempunyai pengaruh buruk untuk lingkungan sekitarnya. Hal ini pula yang menyebabkan kelangsungan hidup mereka merasa terganggu, sehingga kelangsungan hidup yang mereka jalani selanjutnya semakin tidak mudah. Meskipun mereka sudah terlepas dari ketergantungan narkoba dan pernah menjalani proses rehabilitasi, tetapi penilaian masyarakat tetaplah sama, sehingga tidak jarang diantara mereka yang kemudian memiliki kecenderungan untuk kembali memakai narkoba setelah mereka kembali lagi ke masyarakat (Noegroho, 2011).

Remaja penyalahgunaan narkoba membutuhkan kenyamanan dari pasangan hidup, orang tua, anak, saudara, kerabat, teman, rekan kerja serta anggota dalam kelompok kemasyarakatan (Putra, 2011) yang sangat dibutuhkan guna proses kesembuhan remaja pasca penyalahgunaan narkoba.

Proses kesembuhan diperlukan atas motivai diri individu yang bersangkutan, juga diperlukan motivasi dari luar individu untuk mengatasi masa-masa sulit yang dihadapi individu pasca sembuh dari ketergantungan narkoba namun motivasi itu akan terus ada karena mendapatkan dukungan dari orang-orang yang ada disekitarnya (Bachtiar, 2010).

Faktor lain yang dapat mempertahankan diri remaja dari pasca kembuhan narkoba yaitu dengan perkembangan jiwa beragama. Sangatlah penting untuk menerapkan konsep agama pada diri remaja. Menurut AzZa`balawi (2007) Remaja yang memiliki konsep agama yang kuat dalam dirinya disetiap ia menghadapi berbagai hal ia akan berpikir bahwa ia sedang mendapatkan pelajaran dan cobaan serta memperoleh hikmah dari setiap perbuatan yang membinasakan dirinya sendiri. Sedangkan pada remaja yang tidak kuat dengan konsep agama, maka akan mengalami kegagalan yang menyebabkan remaja terperangkap pada perilaku dan perbuatan yang merusak dirinya sendiri.

Kesadaran remaja terhadap keberagamaannya, dapat menghindarkan dirinya dari perbuatan yang dilarang agama, termasuk narkotika, psikotropika, alkohol dan zat adiktif lainnya. Agama merupakan motivator penting dalam memberikan pengarahan dan upaya pencegahan dari zat-zat terlarang tersebut, oleh karena itu para remaja dan generasi muda penerus bangsa yang taat beragama dan dengan disiplin melaksanakan ajaran agama dapat terhindar dari penyalahgunaan narkoba (syafii, 2009).

Melihat kenyataan dilapangan, dapat dilihat bahwa sebagian besar masyarakat sudah banyak pengetahuan mengenai bahaya dari narkoba, namun fenomena yang terjadi sekarang penyalahgunaan tersebut setiap tahun meningkat, semakin banyak remaja yang terlibat kasus narkoba menjadi indikasi betapa besarnya pengaruh narkoba dalam kehidupan remaja saat ini. Perlu diwaspadai, kasus penyalahgunaan narkoba yang terjadi dikalangan remaja kita ibarat fenomena gunung es yaitu kasus yang terlihat hanya sebagian kecil saja, sementara kejadian sebenarnya sudah begitu banyak (Serambi, 2014). Dengan adanya dukungan sosial, remaja penyalahgunaan narkoba memiliki motivasi untuk sembuh sehingga mereka akan kembali memiliki arti dalam kehidupannya.Adapun tujuan dalam penelitian ini adalah untuk mengetahui hubungan antara dukungan sosial dengan motivasi pasca kesembuhan pada remaja penyalahgunaan narkoba di Banda Aceh.

Secara teoritis hasil penelitian ini diharapkan dapat menambah ilmu pengetahuan dan informasi dikalangan akademis khususnya psikologi sosial dan psikologi kesehatan tentang remaja pacsa penyalahgunaan narkoba. Secara praktis, hasil penelitian ini diharapkan dapat memberikan acuan dan informasi yang berarti khususnya pada remaja penyalahguna narkoba sehingga motivasi untuk sembuh menjadi semakin meningkat, sehingga tidak mudah untuk kembali lagi terjerumus kedalam penyalahgunaan narkoba.

Sarafino (dalam Chrismawati, 2008) mengungkapkan bahwa dukungan sosial mengacu pada memberikan kenyamanan pada orang lain, merawatnya atau menghargainya. Dari definisi diatas dapat dilihat dengan jelas bahwa sumber dari dukungan sosial ini adalah orang-orang yang berinteraksi dengan individu, sehingga individu tersebut dapat merasakan kenyamanan secara fisik dan psikologis. 
Menurut Cutrona (dalam Putra, 2011) dukungan sosial merupakan suatu proses hubungan yang terbentuk dengan persepsi bahwa seseorang dicintai, dihargai, disayangi untuk memberikan bantuan kepada individu yang mengalami tekanan-tekanan didalam kehidupannya.

Dukungan sosial yang kita terima dapat bersumber dari berbagai pihak. Kahn \& Antonoucci (dalam Chrismawati, 2008) membagi sumber-sumber dukungan sosial menjadi tiga kategori, yaitu sumber dukungan sosial yang berasal dari orang-orang yang selalu ada sepanjang hidupnya yang selalu bersama dengannya dan mendukungnya. Misalnya keluarga dekat, pasangan (suami atau istri) atau teman dekat. Sumber dukungan sosial yang berasal dari individu lain yang sedikit berperan dalam hidupnya dan cenderung mengalami perubahan sesuai dengan waktu. Sumber dukungan ini meliputi teman kerja, sanak keluarga dan teman sepergaulan. Dan sumber dukungan sosial yang berasal dari individu lain yang sangat jarang memberi dukungan dan memiliki peran yang sangat cepat berubah, meliputi dokter atau tenaga ahli atau profesional dan keluarga jauh.

Dukungan sosial memiliki beberapa bentuk yang berbeda-beda. Menurut Sarafino (dalam Chrismawati, 2008) dukungan sosial terdiri dari empat jenis, yaitu : yang pertama Dukungan emosional, dukungan ini melibatkan ekspresi rasa empati dan perhatian terhadap individu, sehingga individu tersebut merasa nyaman, dicintai dan diperhatikan. Dukungan ini meliputi perilaku seperti memberikan perhatian dan afeksi serta bersedia mendengarkan keluh kesah orang lain. Dukungan penghargaan, dukungan ini melibatkan ekspresi yang berupa pernyataan setuju dan penilaian positif terhadap ide-ide dan perasaan dan performa orang lain. Dukungan instrumental bentuk dukungan ini melibatkan bantuan langsung, misalnya berupa bantuan finansial maupun bantuan dalam mengerjakan tugas-tugas tertentu. Dukungan informasi, dukungan yang bersifat informasi ini dapat berupa saran, pengarahan dan umpan balik tentang bagaimana cara memecahkan persoalan.

Para ahli berpendapat bahwa dukungan sosial dapat dibagi ke dalam berbagai aspek yang berbeda-beda. Misalnya menurut Kuntjoro (dalam Putra, 2011), mengemukakan adanya enam komponen dukungan sosial yang disebut sebagai "The Social Provision Scale", dimana masing-masing komponen dapat berdiri sendirisendiri, namun satu sama lain saling berhubungan. Adapun komponen-komponen tersebut adalah Attachment (kasih sayang atau kelekatan), Social Integration (Integrasi sosial), Reanssurance of Worth (Pengakuan), Reliable Alliance (Ikatan atau hubungan yang dapat diandalkan), Guidance (Bimbingan), Opportunity for Nurturance (Kemungkinan dibantu).
Menurut Simpson (dalam Putra, 2011) motivasi merupakan suatu kondisi dan dorongan yang disebabkan oleh adanya motif atau alasan atau sebab yang muncul dalam diri seseorang yang mendorong ia untuk melakukan usaha-usaha berupa pekerjaan, berperilaku, sikap tertentu dan membuat dirinya menjadi aktif untuk terus berusaha mencapai tujuan.

Motivasi menjadi suatu kekuatan, tenaga atau daya atau suatu keadaan yang kompleks dan kesiapsediaan dalam diri individu untuk bergerak ke arah tujuan tertentu, baik disadari maupun tidak disadari (Djamarah, 2002). Motivasi seseorang dapat ditimbulkan dan tumbuh berkembang melalui dirinya sendiri-intrinsik dan dari lingkungan-ekstrinsik.

Djamarah (2002) menyebutkan motivasi terbagi menjadi 2 (dua) jenis yaitu motivasi intrinsik dan motivasi ekstrinsik. Motivasi intrinsik adalah motif-motif yang menjadi aktif atau berfungsinya tidak perlu dirangsang dari luar, karena dalam setiap diri individu sudah ada dorongan untuk melakukan sesuatu. Motivasi intrinsik datang dari hati sanubari umumnya karena kesadaran yang timbul dari dalam diri.

Djamarah (2002) menyebutkan faktor-faktor yang mempengaruhi motivasi intrinsik yaitu faktor kebutuhan, seseorang melakukan aktivitas (kegiatan) karena adanya faktor-faktor kebutuhan baik biologis maupun psikologis. Remaja pasca penyalahgunaan narkoba membutuhkan aktivitas sehari-hari agar tidak kembali menggunakan narkoba. Faktor selanjutnya harapan, seseorang dimotivasi oleh karena keberhasilan dan adanya harapan keberhasilan bersifat pemuasan diri seseorang, keberhasilan dan harga diri meningkat dan menggerakkan seseorang ke arah pencapaian tujuan. Dan faktor minat, suatu rasa lebih suka dan rasa keinginan pada suatu hal tanpa ada yang menyuruh.

Motivasi ekstrinsik adalah motif-motif yang aktif dan berfungsi karena adanya perangsang atau pengaruh dari orang lain sehingga seseorang berbuat sesuatu (Ahmad, 2012) . Djamarah (2002) menyebutkan faktorfaktor yang mempengaruhi motivasi ekstrinsik adalah adanya dorongan keluarga, lingkungan, dan imbalan yang membuat seseorang melakukannya.

Menurut Simpson (dalam Putra, 2011) motivasi memiliki 3 aspek yaitu aspek problem recognition (pengakuan terhadap masalah), yaitu masalah dalam pengakuan penggunaan napza yang kemungkinan didapat dari tekanan intrinsic seperti keinginan untuk hidup bebas dari narkoba. Aspek desire for help (keinginan untuk dibantu), yaitu mendapatkan bantuan dari keluarga berupa dorongan semangat dan perhatian. Dan aspek treatment readiness (kesiapan mengikuti treatment), yaitu ketika pengguna napza sudah mengakui masalah yang dihadapinya dan keinginan untuk dibantu maka 
selanjutnya kesiapan mengikuti treatment dalam proses kesembuhan.

Pandangan islam tentang narkotika dan minuman keras telah lama dikenal umat manusia. Tapi sebenarnya lebih banyak madharatnya daripada manfaatnya. Untuk itu, hampir semua agama besar melarang umat manusia untuk mengkonsumsi narkotika dan minuman keras (dalam bentuk yang lebih luas lagi adalah narkoba).

Dalam wacana islam, ada beberapa ayat Al-Qur`an dan hadits yang melarang manusia untuk mengkonsumsi minuman keras dan hal-hal yang memabukkan. Pada orde yang lebih mutakhir, minuman keras dan hal-hal yang memabukkan bisa juga dianalogikan sebagai narkoba. Dalam pandangan Islam mengenai narkoba, hukum penyalahgunaan narkoba diqiyaskan pada hukum mengkonsumsi khamar yang disebutkan Didalam AlQur`an terdapat firman Allah :

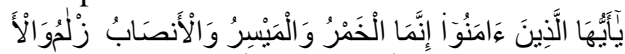

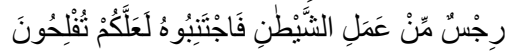

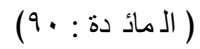

Artinya : Hai orang-orang yang beriman, sesungguhnya (meminum) khamar, berjudi, (berkorban untuk) berhala, mengundi nasib dengan panah adalah perbuatan keji termasuk perbuatan setan. Maka jauhilah perbuatanperbuatan itu agar kamu mendapat keberuntungan (QS. Al-Maidah: 90).

Berdasarkan firman diatas juga dapat dipahami bahwa narkoba dapat diqiyaskan dengan meminum khamar yang sifatnya dapat menyebabkan hilangnya sistem saraf dan sistem akal yang ada pada manusia sehingga dapat terjerat kedalam perbuatan yang keji.

Selain itu perkembangan jiwa beragama pada remaja sangatlah penting, remaja yang memiliki konsep agama yang kuat dalam dirinya disetiap ia menghadapi berbagai hal ia akan berpikir bahwa ia sedang mendapatkan pelajaran dan cobaan, dan memperoleh hikmah dari setiap perbuatan yang membinasakan dirinya sendiri (AzZa'balawi, 2007). Sedangkan pada remaja yang tidak kuat dengan konsep agama, remaja mengalami kegagalan yang menyebabkan remaja terperangkap pada perilaku dan perbuatan yang merusak dirinya sendiri seperti penyalahgunaan narkoba pada remaja.

Hubungan antara dukungan sosial dengan motivasi pasca kesembuhan pada remaja penyalahgunaan narkoba yang terdiri dari narkotika, psikotropika dan zat adiktif ini merupakan obat-obatan yang dapat menimbulkan ketergantungan pada penggunanya, sebab narkoba memiliki sifat ketagihan yang sangat berat, penyesuaian dan kebiasaan yang sangat tinggi (Noegroho, 2011).

Bagi para pengguna narkoba, kesadaran dan kesungguhan dari diri sendiri merupakan modal utama agar mereka bisa lepas dari ketergantungan. Kesadaran diri timbul karena adanya dukungan sosial yang diberikan oleh orang-orang terdekat di sekitar lingkungan tempat tinggal para remaja penyalahgunaan narkoba. Alasan utama para penyalahguna narkoba termotivasi untuk sembuh adalah karena mereka mendapatkan dukungan dari orang-orang terdekat mereka, baik dari keluarga maupun teman-teman dilingkungan mereka.

Motivasi untuk sembuh pada remaja pengguna narkoba adalah suatu daya atau dorongan yang membangkitkan, mengarahkan dan menggerakkan yang ada pada diri remaja untuk pulih kembali ke keadaan sehat badan dari ketergantungan narkoba (Bachtiar, 2010). Beberapa alasan yang dikemukakan oleh para penyalahguna narkoba yang dapat menimbulkan motivasi untuk sembuh pasca dari ketergantungan narkoba tersebut yaitu dirasakannya gejala atau tanda yang menyimpang dari keadaan biasa, banyaknya gejala yang dianggap serius dan dapat menimbulkan bahaya, adanya kebutuhan untuk bertindak atau berperilaku mengatasi gejala sakit itu, ingin lepas dari rasa sakit yang mengganggu aktivitas sehari-hari, merasa belum banyak berbuat baik bagi orang lain serta banyak mendapat dukungan dari keluarga dan teman sehingga masih merasa diperhatikan, dihargai dan dibutuhkan dalam kehidupan selanjutnya (Mustopa, 2011).

Usaha untuk mengatasi masalah penyalahgunaan narkoba pada remaja tidaklah lepas dari pengaruh dukungan sosial, terutama dukungan yang didapatkan dari orang yang berarti bagi individu tersebut, seperti orang tua, pacar atau sahabat.

Dukungan sosial yang diterima individu akan memotivasi para remaja untuk sembuh dari ketergantungan narkoba. Dukungan emosional seperti empati, kepedulian dan perhatian dari orang-orang disekitar dapat membuat individu merasa tenang, diperhatikan, timbul rasa percaya diri dan sebagainya. Hal-hal seperti ini memiliki arti yang besar dalam kehidupan seseorang terutama pada saat stress (Sutanto, 2011).

Dukungan sosial yang didapat dari lingkungan sekitarnya akan menimbulkan perasaan atau sikap positif terhadap diri sendiri sehingga remaja dapat termotivasi untuk sembuh dari ketergantungan narkoba. Orang yang memperoleh dukungan sosial yang tinggi mengalami hal yang positif dalam kehidupannya, mempunyai harga diri yang lebih tinggi dan mempunyai pandangan lebih optimis terhadap kehidupannya dibandingkan dengan orang yang mendapatkan dukungan sosial yang rendah.

Berdasarkan teori yang telah diuraikan diatas, keterkaitan antara dukungan sosial dengan motivasi pasca kesembuhan pada remaja penyalahgunaan narkoba, maka penulis mengajukan hipotesis bahwa ada hubungan antara 
dukungan sosial dengan motivasi pasca kesembuhan pada remaja penyalahgunaan narkoba.

\section{METODE}

Penelitian ini menggunakan pendekatan kuantitatif yaitu berupa penelitian causal research adalah desain riset yang bertujuan untuk membuktikan hubungan sebab akibat dari variabel yang diteliti. Menggunakan metode kuantitatif merupakan suatu metode yang memiliki data penelitian berupa angka-angka dan dianalisis menggunakan statistik kemudian pengambilan keputusan dan kesimpulan penelitian berdasarkan hasil analisis statistik tersebut. Penelitian ini menggunakan analisis korelasi ganda yang bertujuan menguji hubungan antara dua atau lebih kelompok variabel

Dalam penelitian ini teknik yang digunakan adalah sampling jenuh yaitu penentuan sampel apabila semua anggota populasi digunakan sebagai sampel. Hal ini sering dilakukan bila jumlah populasi relatif kecil. Sampel terdiri dari subjek remaja yang mengalami pasca kesembuhan penyalahgunaan narkoba yang telah direhabilitasi dan tergabung dalam komunitas pasca penyalahgunaan narkoba yang ada di Banda Aceh. yang diambil 40 subjek remaja laki-laki pasca rehabilitasi dan berusia 15 - 25 tahun.

Pengumpulan data menggunakan skala dukungan sosial dan skala motivasi. Jenis skala yang digunakan adalah skala likert, skala ini digunakan untuk mengukur sikap, pendapat, dan persepsi seseorang atau sekelompok orang tentang fenomena sosial terhadap suatu pernyataan. Prosedur dalam penelitian ini berupa pembagian skala dukungan sosial dan skala motivasi diberikan pada saat pertemuan atau silaturahhmi remaja pasca pengguna narkoba.

Analisis yang digunakan dalam penelitian ini yaitu analisis korelasi ganda yang digunakan untuk mengetahui adanya hubungan dukungan sosial dengan motivasi remaja. Sesuai dengan hipotesis dan tujuan penelitian untuk mengetahui hubungan, maka data yang diperoleh akan diuji dengan menggunakan uji syarat yaitu uji normalitas dan uji linieritas.

\section{HASIL PENELITIAN DAN PEMBAHASAN}

Penelitian merupakan salah satu tahapan yang harus dilakukan sebelum melakukan penelitian. Hal ini bertujuan untuk mengenal kancah penelitian secara detail serta membantu peneliti agar dapat mempersiapkan segala sesuatu yang berhubungan dengan penelitian yang akan dilakukan. Untuk memdapatkan informasi tentang fenomena-fenomena permasalahan penelitian yang diperlukan, peneliti awalnya melakukan observasi dan wawancara yang mengacu pada sampel yang diinginkan.
Peneliti memilih tempat penelitian pada komunitas remaja pasca penyalahgunaan narkoba yang berada di seputaran Banda Aceh, karena peneliti mendapatkan data yang dapat mewakili subjek penelitian seperti yang telah peneliti paparkan sebelumnya. Awalnya komunitas ini berdiri sendiri dengan program yang ada hanya dikhususkan pada pecandu yang menjalani rehabilitasi, melihat banyaknya pengguna setelah menjalani masa rehabilitasi, ada banyak dari mereka yang kembali lagi sebagai pecandu ini dikarenakan faktor lingkungan yang sangat tidak mendukung serta tidak adanya penguat yang dapat membuat mereka dapat bertahan, maka dari itu perlunya kelompok positif untuk membantu pemulihan pecandu yang telah selesai rehabilitasi sehingga berdirilah komunitas pasca penyalahgunaan narkoba.

Uji reliabilitas dalam penelitian ini menggunakan formula Alpha Cronbachs. Dari hasil uji reliabilitas skala motivasi kesembuhan sebelum dibuang aitem buruk adalah 0,899 dari 40 aitem. Sedangkan hasil uji reliabilitas skala dukungan sosial sebelum aitem buruk dibuang adalah 0,930 dari 40 aitem.

Kemudian hasil uji reabilitas skala motivasi kesembuhan setelah aitem buruk terbuang adalah 0,913 dari 28 aitem yang valid. Sedangkan hasil uji reliabilitas skala dukungan sosial setelah aitem buruk dibuang adalah 0,935 dari 31 aitem yang valid. Sedangkan Koefisien reabilitas kedua variabel setelah aitem buruk terbuang menunjukkan bahwa kedua variabel telah memenuhi persyaratan keandalan alat ukur.Sebelum melakukan analisis data, terlebih dahulu dilakukan uji asumsi terhadap data penelitian yang meliputi uji normalitas, uji lineritas dan uji korelasi.

Uji normalitas adalah uji yang dilakukan untuk melihat data penelitian berasal dari populasi yang sebarannya normal. Uji ini perlu dilakukan karena semua perhitungan statistic parametric memiliki asumsi normalitas sebaran. Formula yang digunakan untuk melakukan suatu uji normalitas dengan mengasumsikan bahwa data yang akan dianalisis berasal dari populasi yang sebarannya normal.

Uji normalitas dilihat melalui tehnik Kolmogorov Smirnov Test dengan menggunakan program SPSS 16.00 for windows. Kaidah yang digunakan untuk menyetujui normalitas data adalah jika nilai signifikansi $\mathrm{p}>0,05$ maka data berdistribusi normal, maka sebaliknya (Hadi, 2004). Hasil dapat dilihat pada tabel 1.

Tabel 1. Uji normalitas

\begin{tabular}{|l|c|c|c|}
\hline \multicolumn{1}{|c|}{ Skala } & $\begin{array}{c}\text { Kolmogorov- } \\
\text { Smirnov }^{\mathbf{a}}\end{array}$ & $\mathbf{P}$ & Keterangan \\
\hline $\begin{array}{l}\text { Motivasi } \\
\text { Kesembuhan }\end{array}$ & 0,619 & 0,838 & Normal \\
\hline $\begin{array}{l}\text { Dukungan } \\
\text { Sosial }\end{array}$ & 0,580 & 0,889 & Normal \\
\hline
\end{tabular}


Berdasarkan tabel diatas Untuk skala motivasi K-SZ $=0,619$ dengan $\mathrm{p}=0,838(\mathrm{p}>0,05)$. Untuk skala dukungan sosial nilai $\mathrm{K}-\mathrm{SZ}=0,580$ dengan $\mathrm{p}=0,889(\mathrm{p}$ $>0,05)$. Hasil nomalitas ini menunjukkan bahwa kedua alat ukur tersebut memiliki sebaran normal.

Uji linieritas merupakan suatu prosedur yang digunakan untuk mengetahui status linear atau tidaknya suatu distribusi data penelitian (Putra, 2011). Uji linearitas dilakukan untuk mengetahui hubungan antara dukungan sosial dengan motivasi kesembuhan linear atau tidak (Hadi, 2004). Dua Variabel dikatakan linear apabila nilai $\mathrm{p}<0,05$, untuk melihat uji linearitas, peneliti menggunakan Test for Linearity dengan menggunakan program SPSS 16.00 for windows. Untuk lebih jelasnya dapat dilihat tabel 2.

Tabel 2. Uji Linieritas

\begin{tabular}{|l|l|l|l|}
\hline Variabel & F & P & Keterangan \\
\hline $\begin{array}{l}\text { Motivasi } \\
\text { Kesembuhan }\end{array}$ & 69,479 & 0,000 & Linear \\
\cline { 1 - 1 } $\begin{array}{l}\text { Dukungan } \\
\text { Sosial }\end{array}$ & & & \\
\hline
\end{tabular}

Berdasarkan tabel diatas hasil pengujian linieritas kedua variabel motivasi dengan dukungan sosial diperoleh nilai $F=69,479$ dengan $p=0,000(p<0,05)$ adalah linier. Maka dapat disimpulkan bahwa asumsi linier dalam penelitian ini terpenuhi.

Setelah selesai melakukan uji normalitas dan uji linieritas maka selanjutnya akan dilakukan uji korelasi antara dukungan sosial dengan motivasi menggunakan analisis Product Moment dari Kart Pearson. Hasil uji korelasi yang menggunakan SPSS Windows 16.00 dapat dilihat pada tabel 3 .

Tabel 3. Analisis Uji Korelasi

\begin{tabular}{|c|c|c|c|}
\hline Skala & Analisis & $\begin{array}{l}\text { Dukugan } \\
\text { sosial }\end{array}$ & $\begin{array}{l}\text { Motivasi } \\
\text { kesembuhan }\end{array}$ \\
\hline \multirow{3}{*}{$\begin{array}{l}\text { Motivasi } \\
\text { Kesembu- } \\
\text { han }\end{array}$} & $\begin{array}{l}\text { Pearson } \\
\text { Correlation }\end{array}$ & 1 & $.819^{* *}$ \\
\hline & $\begin{array}{l}\text { Sig. } \\
\text { tailed) }\end{array}$ & & .000 \\
\hline & $\mathrm{N}$ & 40 & 40 \\
\hline \multirow{3}{*}{$\begin{array}{l}\text { Dukungan } \\
\text { Sosial }\end{array}$} & $\begin{array}{l}\text { Pearson } \\
\text { Correlation }\end{array}$ & $.819^{* *}$ & 1 \\
\hline & $\begin{array}{ll}\text { Sig. } & (2- \\
\text { tailed }) & \end{array}$ & .000 & \\
\hline & $\mathrm{N}$ & 40 & 40 \\
\hline
\end{tabular}

Berdasarkan tabel diatas dari hasil korelasi yang didapat antara dukungan sosial dengan motivasi kesembuhan maka diperoleh hasil $\mathrm{r}=0,819$ dan nilai $\mathrm{p}=$ $0,000$ ( $\mathrm{p}<0,05)$. Hal ini menunjukkan hipotesis dalam penelitian ini telah terbukti diterima, artinya ada hubungan positif yang signifikan antara dukungan sosial dengan motivasi.

Hasil uji tersebut menunjukkan angka koefisien korelasi $\mathrm{r}=0,819$ mengidentifikasikan bahwa ada hubungan positif yang signifikan antara dukungan sosial dengan motivasi. Berdasarkan data diatas maka dapat disimpulkan bahwa semakin tinggi dukungan sosial maka semakin tinggi pula motivasi kesembuhan remaja pasca penyalahgunaan narkoba dan sebaliknya semakin rendah dukungan sosial semakin rendah pula motivasi kesembuhan pada remaja penyalahgunaan narkoba.

Penelitian yang mendukung juga dilakukan oleh Chrismawati (2008) motivasi untuk sembuh pada remaja penyalahgunaan narkoba ditinjau dari dukungan sosial (studi di Yayasan Wahana Sejahtera Harm Reduction Semarang), berdasarkan hasil analisis data diperoleh $r=$ 0,488 ( $\mathrm{p}<0,00)$ menyimpulkan bahwa ada hubungan positif antara dukungan sosial dan motivasi sembuh pada remaja penyalahgunaan narkoba.

Penelitian yang dilakukan Putra (2011) hubungan antara dukungan sosial dengan motivasi sembuh pada pengguna napza (Studi Direhabilitas Madani Mental Health Care), berdasarkan hasil analisis data diperoleh $\mathrm{r}$ $=0,435(\mathrm{p}<0,00)$. Hasil tersebut juga signifikan sehingga mendukung penelitia yang telah dilakukan.

Dukungan sosial merupakan suatu hal yang sangat penting untuk memotivasi remaja pasca kesembuhan penyalahgunaan narkoba, dukungan sosial yang dapat diperoleh dari orang-orang terdekat seperti keluarga, orang tua, teman sebaya maupun lingkungan. Dukungan sosial dan motivasi saling berhubungan yang dapat membantu kesembuhan remaja pasca penyalahgunaan narkoba.

Remaja pasca penyalahgunaan narkoba sangat memerlukan dukungan sosial untuk kesembuhannya dalam penyalahgunaan narkoba, sebagaimana yang diungkapkan Cutrona (dalam Putra, 2011) dukungan sosial merupakan suatu proses hubungan yang terbentuk dengan persepsi bahwa seseorang dicintai, dihargai, disayangi untuk memberikan bantuan kepada individu yang mengalami tekanan-tekanan didalam kehidupannya. Selain dukungan sosial motivasi juga sangat dibutuhkan dalam proses penyembuhan remaja penyalahgunaan narkoba sebagaimana pendapat menurut Simpson (dalam Putra, 2011) motivasi merupakan suatu kondisi dan dorongan yang disebabkan oleh adanya motif, alasan atau sebab yang muncul dalam diri seseorang yang mendorong ia untuk melakukan usaha-usaha berupa pekerjaan, berperilaku, sikap tertentu dan membuat dirinya menjadi aktif untuk terus berusaha mencapai tujuan. Dukungan sosial sangat penting bagi remaja pasca kesembuhan penyalahgunaan narkoba dikarenakan dukungan yang diberikan dapat membantu remaja dalam proses kesembuhan, semakin tinggi dukungan sosial maka semakin tinggi pula motivasi kesembuhan remaja pasca penyalahgunaan narkoba dan sebaliknya. Semakin rendah 
dukungan sosial semakin rendah pula motivasi kesembuhan pada remaja penyalahgunaan narkoba.

Berdasarkan hasil penelitian menunjukkan bahwa ada hubungan yang positif antara dukungan sosial dengan motivasi kesembuhan pada remaja penyalahgunaan narkoba di Banda Aceh dengan jumlah subjek sebayak 40 orang. Uji korelasi dilakukan untuk mengetahui hubungan antara dukungan sosial dengan motivasi kesembuhan. Hal ini sesuai dengan hasil analisis data yang menggunakan korelasi Product Moment yang ditunjukkan oleh koefisien korelasi $\mathrm{r}=0,819$ dengan nilai $\mathrm{p}=0,000 \quad(\mathrm{p}<0,05)$ artinya dukungan sosial secara signifikan mempengaruhi motivasi secara positif.

Hubungan antara kedua variabel menunjukkan bahwa semakin tinggi dukungan sosial maka semakin tinggi pula motivasi kesembuhan remaja pasca penyalahgunaan narkoba dan sebaliknya. Semakin rendah dukungan sosial semakin rendah pula motivasi kesembuhan pada remaja penyalahgunaan narkoba. Jadi dapat disimpulkan hipotesis dalam penelitian ini dapat diterima atau Ha diterima dan Ho ditolak.

Berdasarkan hasil penelitian, kategorisasi dukungan sosial dan motivasi untuk sembuh dapat diketahui dukungan sosial yang diperoleh berada dalam kategori rendah (68-84) ada 8 subjek, sedang (85-110) ada 25 subjek dan tinggi (111-122) ada 7 subjek.

Diterimanya hipotesis dalam penelitian ini menunjukkan bahwa dukungan sosial mempunyai peranan dalam motivasi kesembuhan pada remaja pasca penyalahgunaan narkoba. Banyaknya dukungan sosial yang diberikan akan menjadi salah satu peran penting dalam diri remaja pasca penyalahgunaan narkoba. Dukungan sosial merupakan suatu proses hubungan yang terbentuk dengan persepsi bahwa seseorang dicintai, dihargai dan disayangi untuk memberikan bantuan kepada individu yang mengalami tekanan-tekanan didalam kehidupannya. Terkait dengan proses hubungan dukungan sosial dengan motivas pada remaja pasca penyalahgunaan narkoba, maka dalam penelitian ini teori sangatlah penting untuk mendukung penelitian ini serta menjelaskan fenomena yang terjadi sehingga antara teori dengan fakta yang ada sesuai.

\section{PENUTUP}

\section{Simpulan}

Berdasarkan hasil penelitian dan pembahasan yang telah dilakukan dalam penelitian "Hubungan antara Dukungan Sosial dengan Motivasi Pasca Kesembuhan pada Remaja Penyalahgunaan Narkoba di Banda Aceh" dapat disimpulkan ada hubungan yang signifikan antara dukungan sosial dengan motivasi pasca kesembuhan pada remaja penyalahgunaan narkoba dengan nilai koefisien $r$
$=0,819$ yang berarti reliabel dengan nilai $\mathrm{p}=0,000(\mathrm{p}<$ $0,05)$.

Hal ini menunjukkan bahwa semakin tinggi dukungan sosial yang mereka dapat dari lingkungan sekitar, maka semakin tinggi pula motivasi mereka untuk tidak kembali lagi menggunakan narkoba. Begitu pula sebaliknya, rendahnya dukungan sosial yang mereka terima berpengaruh rendah juga terhadap motivasi mereka untuk kembali lagi menggunakan narkoba. Hal ini menunjukkan bahwa hipotesis yang diajukan dapat diterima.

\section{Saran}

Sesuai dengan hasil penelitian, maka berikut ini ada beberapa saran yang diberikan oleh peneliti yaitu, secara praktis, hasil penelitian ini diharapkan dapat bermanfaat bagi individu penyalahgunaan narkoba, penelitian ini dapat dijadikan bahan acuan untuk lebih menerima dan merasakan dukungan sosial yang sudah dimiliki sehingga dapat memacu untuk lebih termotivasi dalam kesembuhan diri dari narkoba.

Orang tua dan keluarga agar lebih memperhatikan bahaya dari penyalahgunaan narkoba serta memberikan dukungan dan motivasi untuk kesembuhan. Panti Rehabilitasi tidak hanya memberikan pengobatan fisik namun juga memberikan psikis yang sangat dibutuhkan, baik pada remaja pasca pengguna narkoba diberikan penyuluhan-penyuluhan agar tidak kembali menggunakan narkoba. Pemerintah dapat memberikan perhatian lebih tidak hanya pada pengguna narkoba namun juga pada pasca pengguna narkoba agar memberi penghargaan yang meliputi penyediaan lapangan pekerjaan agar mereka diterima dilingkungan masyarakat.

Bagi peneliti selanjutnya yang ingin meneliti dengan judul yang sama, diharapkan kepada peneliti sebaiknya mengkaji lebih dalam aspek-aspek dan teori yang akan digunakan serta menambah variabel-variabel yang mendukung seperti kepercayaan diri, tingkat stres, persepsi dan tingkat pendidikan atau peneliti selanjutnya menggunakan metode kualitatif untuk memperoleh informasi lebih mendalam. Selanjutnya peneliti lebih menggali aspek-aspek yang sangat mendukung pada pasca penyalahgunaan narkoba. Selain itu sebaiknya melakukan pendekatan dan raport agar subjek lebih berminat dalam mengisi skala

\section{DAFTAR PUSTAKA}

Ahmad. 2012. Pengertian teori-teori motivasi. http://aliakhmad.blogspot.com/2012/07/pengertianmotivasi-dan-teori-teori.html diakses pada 20 November 2014

Az-Za'balawi, M. S. M. 2007. Pendidikan Remaja antara Islam \& Ilmu Jiwa. Gema Insani 
Bachtiar, A. 2010. Psiklogi Teori-teori Motivasi. http://bachtararif.blogspot.com /2010/10/dalampengetahuan-psikologi-kita-seri ng.html diakses pada 8 April 2015

BNN. 2014. Penyalahgunaan Narkoba dan Upaya Penanggulangannya. Jakarta: Badan Narkotika Nasional.

Crhismawati, F. 2008. Motivasi Untuk Sembuh pada Remaja Penyalahguna Narkoba Ditinjau dari Dukungan Sosial. Skripsi. Semarang : Fakultas Psikologi Katolik Soegijapranata.

Djamarah. 2002. Teori Motivasi, edisi 2 (ed-2), Jakarta : PT. Bumi Aksara.

Gunarsa, S. D. 2001. Psikologi Praktis: Anak, Remaja dan Keluarga. Jakarta: PT. BPK Gunung Mulia.

Hadi, A. 2004. Metodelogi Research. Yogyakarta : Andi Offset.

Mustopa, A. 2011. Teori Motivasi. http://alimustopa.blogspot.com/2011/11/teori-motivasi.html diakses pada 8 April 2014.

Noegroho, A. 2011. Mengenal Penggolongan Narkotika dan Psikotropika. http://agoes-nff04.web.unair.ac.id/artikel_detail-35300-NapzaMengenal\%20Penggolongan\%20Narkotika\%20dan $\% 20$ Psikotropika.html. (online) diakses pada tanggal 19 November 2014.

Putra, B.S. 2011. Hubungan antara Dukungan Sosial dengan Motivasi Untuk Sembuh pada Pengguna Napza di Rehabilitasi Madani Health Care. Skripsi. Jakarta : Fakultas Psikologi Universitas Islam Negeri Syarif Hidayatullah.

Q.S Almaidah. 2005. Al-Quran Terjemahan. Jakarta: Raja Grafindo Persada.

Serambi. 2014. Aceh Darurat Narkoba. Serambi 18 Juli 2014. Banda Aceh : PT Serambi Indonesia.

Sutanto, T. 2011. Dukungan Sosial. http://jalurilmu.blogspot.com/2011/10/dukungansosial.html. (online) diakses pada tanggal 13 November 2014.

Syafii, A. 2009. Pengaruh Narkoba Terhadap Kenakalan Remaja di Sulawesi Tengah. Media Litbang Sulteng, 2(2).

Tabrani, Y. 2015. Bangsa Yang Didera Narkoba. http://www.kompasiana.com/tabraniyunis/bangsayang-didera-narkoba_5584321cef7e61270a8b456f. (online) diakses pada 15 Juni 2015. 